\title{
Determinants of user demand for lifelong learning in institutions of higher education
}

\author{
Betlem Sabrià-Bernadó, Xavier LLinàs-Audet and \\ Sofia Isus Barado
}

\begin{abstract}
The main objective of this study is to identify the determinants that influence user demand for lifelong learning in institutions of higher education. Qualitative methodology was used to develop an instrument and a quantitative approach was used for the remainder of the study. After a literature review and indepth interviews with experts in lifelong learning, we obtained the dimensions of the study and validated a questionnaire using expert opinion and a pilot test. The results and conclusions drawn from this study indicate the existence of three dimensions in user demand for lifelong learning in institutions of higher education: motivational, conflicts/difficulties and career-development. The constructs of current-work, careerchange and personal improvement are linearly related to the motivational dimension; personal-constructs, external and time-related constructs are linked to the conflict/difficulties dimension; and working-environment and professionalexperience constructs are related with the career development dimension. One of the novel contributions of this work is that it obtains empirical evidence on the determinants of demand for lifelong learning from the perspective of people who seek training.
\end{abstract}

\section{Introduction}

The selection and training period for working in a profession is not a decisive or unique life event, but rather an ongoing process. In this context, the concept of lifelong learning acquires importance. Knowledge has an expiration date and it is necessary to acquire new skills to meet changing work situations.

$\square$ Betlem Sabrià-Bernadó, Universitat d'Andorra, Andorra. Email: bsabria@uda.ad. Xavier LLinàs-Audet, Universitat Politècnica de Catalunya, Spain. Email: xavier.llinas@upc.edu. Sofia Isus Barado, Universitat de Lleida, Spain. Email: sisus@pip.udl.cat 
The training needs of citizens extend beyond initial professional studies and last a lifetime. Professionals must be continuously learning (Marcelo, 2010; St Pierre \& Kustcher, 2001). When lifelong learning takes place in institutions of higher education the assessments that students make of themselves and the changing world are crucial $(\mathrm{Su}, 2011)$. Lifelong learning is acquired in different types of courses that all affect the student's curriculum (Idrus et al., 2012).

During the last decade, lifelong learning has been high on the European political agenda of cooperation in education and training. European Union ministers are convinced of its importance and have agreed that by 2020 at least 15 per cent of adults should be receiving training and education (Eurydice Network, 2011).

The overall objective of this study was to identify the determinants of demand for continuous training among users in Institutions of Higher Education.

Most studies analyse the demand for lifelong learning from the perspective of organizations. One of the novel contributions of this work is that it obtains empirical evidence on the determinants of the demand for lifelong learning from the perspective of people who seek training. We intended to bring knowledge into this field that could be useful for institutions of higher education and for other participants when designing new academic programs or training.

The fundamental contribution of this study is an explanatory model of the factors of each of the dimensions that influence users' demand for continuing education in institutions of higher education on the basis of the variables and their corresponding measuring instruments. The results obtained may help such institutions in the planning of future training and future students to make them reflect on their training throughout life as well as the importance of their training curriculum, as it can help in the development of professional opportunities in a flexible and changing labour market.

\section{Literature review}

One of the earliest references to lifelong learning appeared in 1919 in the Final Report of the Adult Education Committee of the UK Ministry of Reconstruction as cited in Sutherland and Crowther (2007). The report considered that training throughout life is ideal for everyone. This concept has evolved over time and in 1976 UNESCO referred to lifelong learning as an action that affects all the dimensions of an individual (quoted in Ruiz, 2001): 'The term lifelong learning means an overall scheme aimed at restructuring the existing education system and developing all training opportunities that are outside the education system' (p. 12).

There are many definitions of lifelong learning, but we consider one of the most appropriate to be that of the Commission of the European Communities (2000) as cited in the Memorandum on Lifelong Learning: 'Any activity continuously made for the purpose of enhancing skills, knowledge and abilities' (p. 9).

Later the European Parliament and Council (2006a) extended this concept and stated:

Lifelong learning or continuing education includes all activities of general education, vocational education and training, informal education and training that takes place throughout life and enhances knowledge, skills and abilities in a personal, civic, social, or working perspective (European Parliament and Council, 2006b).

One of the objectives of the European Union since its inception has been the development of quality training among its member states. Concern for education has been increasing over the years as highlighted in Table 1.

Education and training are useful tools for achieving long-term goals. We conclude that the European Union believes that such education is essential for achieving adequate levels of growth and employment, and an efficient investment in human capital. On this point, presented and sorted chronologically, some of the studies related to continuous training, organizations and training users.

The motivation to learn depends on four variables: the reaction of the participant, the expectations of success, the attitude and the work environment (Noe, 1986). 


\begin{tabular}{|c|c|}
\hline Year & Action \\
\hline 1992 - Maastricht Title VIII & $\begin{array}{l}\text { Creation of European Union. Various chapters } \\
\text { devoted to education and training. }\end{array}$ \\
\hline $\begin{array}{l}1993 \text { - Brussels: White Paper } \\
\text { on Growth, Competitive- } \\
\text { ness and Employment }\end{array}$ & $\begin{array}{l}\text { Stressed importance of education and training as } \\
\text { factors contributing to economic and social } \\
\text { change. }\end{array}$ \\
\hline $\begin{array}{l}1995 \text { - EU Commission } \\
\text { published the 'White Paper } \\
\text { on Education and Training: } \\
\text { Teaching and Learning. } \\
\text { Towards the knowledge } \\
\text { society'. }\end{array}$ & $\begin{array}{l}\text { Council of Europe declared } 1996 \text { as 'European Year } \\
\text { of Education and Lifelong Learning'. }\end{array}$ \\
\hline $\begin{array}{l}2000 \text { - Lisbon. European } \\
\text { Council. Refers specifically } \\
\text { to lifelong learning in para- } \\
\text { graphs } 25 \text { and } 26 .\end{array}$ & $\begin{array}{l}\text { New strategic goal set for the next decade that } \\
\text { strongly drives lifelong learning - Becoming a } \\
\text { knowledge based, competitive global economy } \\
\text { that is capable of sustainable economic growth } \\
\text { with more and better jobs and greater social } \\
\text { cohesion (European Council, 2000). A work pro- } \\
\text { gramme was created: 'Economy and Training } \\
2010^{\prime} \text { and the Grundvitg program for adult edu- } \\
\text { cation was created. }\end{array}$ \\
\hline $\begin{array}{l}2000 \text { - EU Commission pub- } \\
\text { lished a Memorandum of } \\
\text { Lifelong Learning }\end{array}$ & $\begin{array}{l}\text { Considers the encouragement of lifelong learning } \\
\text { as a guiding principle in the provision of services } \\
\text { and participation. Recognizes lifelong learning as } \\
\text { a key concept in a new educational approach, } \\
\text { which includes all types of teaching and learning. }\end{array}$ \\
\hline $\begin{array}{l}2002 \text { - European Council } \\
\text { Barcelona }\end{array}$ & $\begin{array}{l}\text { Confirms the 'Education and Training } 2010^{\prime} \text { pro- } \\
\text { gramme. Establishes a solid framework for coop- } \\
\text { eration in education and training that is based on } \\
\text { common goals. }\end{array}$ \\
\hline $\begin{array}{l}2006 \text { - European Parliament } \\
\text { and Council of Europe }\end{array}$ & $\begin{array}{l}\text { A detailed lifelong learning action plan is estab- } \\
\text { lished. The programme objectives are to contrib- } \\
\text { ute through lifelong learning to the development } \\
\text { of the union as an advanced knowledge society } \\
\text { that enjoys sustainable economic growth with } \\
\text { more and better jobs and greater social cohesion, } \\
\text { while protecting the environment for the benefit } \\
\text { of future generations. }\end{array}$ \\
\hline $\begin{array}{l}2010 \text { - European Parliament } \\
\text { and Council of Europe }\end{array}$ & $\begin{array}{l}\text { Adopts 'Europe } 2020 \text { '. One of the goals is to make } \\
\text { lifelong learning and learner mobility a reality. }\end{array}$ \\
\hline $\begin{array}{l}2012 \text { - European Commission } \\
\text { Council }\end{array}$ & $\begin{array}{l}\text { Proposed new working priorities for } 2012-2014 \text { to } \\
\text { mobilize education and training to contribute to } \\
\text { 'Europe } 2020^{\prime} \text {. }\end{array}$ \\
\hline $\begin{array}{l}2013 \text { - European Parliament } \\
\text { and Council of Europe }\end{array}$ & $\begin{array}{l}\text { Interim evaluation reports of the current lifelong } \\
\text { learning programmes stressed importance of EU } \\
\text { action being responsive to lifelong learning and } \\
\text { advocating a simple, flexible and easy to use } \\
\text { approach. }\end{array}$ \\
\hline $\begin{array}{l}2014 \text { - European Parliament } \\
\text { and Council of Europe }\end{array}$ & $\begin{array}{l}\text { Rules set for data collection for survey of adult par- } \\
\text { ticipation in lifelong learning for the period } 2016 \\
\text { and } 2017 \text {. }\end{array}$ \\
\hline
\end{tabular}

Source: Compiled from European Union Official Journal. 
Productivity increases when training programs are implemented (Bartel, 1994). Huselid (1995) studies the links between high-performance work practices and the development of the company. These practices have an economical impact on the business volume business and worker productivity intermediates. A 10 per cent increase in training could mean a 4.9 per cent increase of the productivity in manufacturing companies although a 5.9 per cent increase in training did not mean an increase in manufacturing (Black \& Lynch, 1996). Delery and Doty (1996) demonstrate the hypothesis of existence of a positive relationship between the financial development of the organization and the formal systems of education. The relationship between the improvement of the capabilities of human resources managers and productivity was found by Huselid et al. (1997).

A conceptual model which relates the direct effects of intangible resources on business performance; the training-related resources are critical in creating continuous competitive advantages was developed by Olavarrieta and Friedmann (1999). Kazamaki and Lindh (1999) found that training increases long term working demand, although in the short term, the elasticity of the training on demand is negative and low in absolute value. Technologically similar production lines achieved improvements in uptime and product quality when it is introduced by innovative human resources management practices (Ichniowski \& Shaw, 1999).

The cost/benefit return rate in function of a training day is 1.8 per cent (Bartel, 2000). Barrett and O'Connell (2001) concluded that the general training has a positive effect on the productivity growth. The majority of companies in the United Kingdom did not realize the potential of training in terms of increase in productivity. Only 25 per cent of companies in this country have measured the effectiveness of their programs (Tennant et al., 2002). The results of Bassi et al. (2002) indicated that the investment in training can be used to predict future market returns.

A significant portion of the variation in the motivation to improve work through learning is explained by the commitment to work, positive affectivity and extraversion (Naquin \& Holton, 2002, 2003). High training has a positive effect on performance in factors such as customer loyalty and employee satisfaction (Molina \& Ortega, 2003). Johannessen and Olsen (2003) presented a model of performing training in the workplace, which established that to produce sustainable competitive advantage, it is necessary to join the tacit knowledge to the explicit. An increase in spending on training of managers becomes an improvement in productivity and effectiveness (Aragón et al., 2003). Sterck and Baert (2003) postulated that for an optimal configuration of learning it was necessary that there existed a direct involvement between the organization and the employees in the programming of the training.

The academic qualifications obtained influence job performance (Myers et al., 2004). Arulampalam et al. (2004) revealed that in the public sector employees have a greater tendency towards learning than those in the private sector. Women who received additional training in their work obtained, on average, a 2 per cent increase in salary (Chu-Ng, 2005). Ubeda (2005) found that the development of human capital has a positive impact on customer satisfaction, employees, customers and shareholders or owners.

The consolidation of the training department within the organization's structures, the size of a company and their business volume are key variables of training (Eguiguren-Huerta et al., 2006; Solé-Parellada et al., 2006). Training related to the job leads to increased productivity (Dearden et al., 2006). They suggested the formation of externalities. However, Ballot et al. (2006) measured productivity such as the wage indicator and found that the return on investment in training is low. Empowerment represented a gain of roughly 7 per cent and extensive training of 6 per cent of the value added of the worker (Birdi et al., 2008).

Without obtaining empirical evidence Vlachos (2008) concluded that the intensive training ensured the presence of employees with the proper rating, and this fact leads to the production of products of better quality. Danvila and Sastre (2009) demonstrated empirically the existence of the relationship between total quality and the efforts made in training. The two main reasons why adults do nonformal training were to get a better job and improve the career prospects and to increase knowledge and/or skills in an 
interesting topic. The two main obstacles to continuous training are hours of work and family responsibilities (Boateng, 2009). Mamaqi and Miguel (2011) obtained an empirical evidence and they showed that the failure to provide a specific training with agreement between the employee and the organization, depending on their initial education, experience and occupational category of the worker contributes to improving the stability and employment of the worker.

An organization that has a good image in reference to facilitate training of their employees, had a positive influence on the demand for training of these; create a culture of learning within the organization and at the same time helps to attract and retain key employees (Noe et al., 2010). A climate in the organization that promotes learning influences positively on the promotion of the participation of their employees in learning activities (Noe et al., 2010). Younger workers and those who have less time in the Organization were more stimulated by do training (Kyndt et al., 2011).

If organizations wanted to retain their employees, it was important to take care of their education (Govaerts et al., 2011). In the public sector employees had a greater tendency to the learning instead of employees in the private sector (Findlay et al., 2012). Education could focus as a factor of economic growth. It generates a virtuous circle that allows the reduction of the gap between the skilled and unskilled labour. Knowledge represents a competitive advantage (Milanovic, 2011; Silvi \& Cuganesan, 2006).

Pastor et al. (2011) carried out a study that focuses on the analysis of the continuous training in Spain and got empirical evidence that larger companies promoted more training in their employees, particularly in the University. They also found training and productivity to be related. Busemeyer et al. (2012) argued and demonstrated empirically that the level offered by the training company to its employees is strongly correlated with the size of the company. Large companies are more likely to offer training programmes.

The most valuable asset of the institution of the 21st century in a knowledge economy, will be the employees with their knowledge and their productivity (Fajar \& Hidajat, 2012). Training helps in retaining within the organization of qualified employees (Maluti et al., 2012).

Delmas and Pekovic (2013) studied the relationship between environmental standards and labour productivity, and concluded that the training of workers is a mediation mechanism for environmental rules and affects productivity. There was a positive relationship between training and productivity (De Grip \& Sauermann, 2013). The authors believed that more multidisciplinary studies are needed on this topic, which finds a black box. The learning conditions indicated that support of the supervisor is critical for an employee to apply the competences developed during a training programme in the job (Govaerts \& Dochy, 2014).

The interactions between knowledge, learning and business leaders to facilitate conditions conducive to innovation (Švarc \& Dabić, 2017). The learning conditions information, feedback, reflection and coaching was good predictors for the acquisition of generic learning outcomes and organizational level learning outcomes (Janssens et al., 2016). Formal and informal learning influences job performance through the value of learning at work (Park \& Choi, 2016).

\section{Methodology}

Consistent with the objectives we used a hybrid methodology - qualitative for the indepth interviews and quantitative in the survey. The phases of the study are showed in Figure 1.

The first step of the study is the design and validation of an instrument that allows us to determine the factors that influence on the users' demand of training in Institutions of Higher Education. Validation has been done in two ways: a trial experts and a pilot test.

For the instrument design, we have performed focused and directed interviews, because we wanted to focus on asking about factors that can influence the performance 


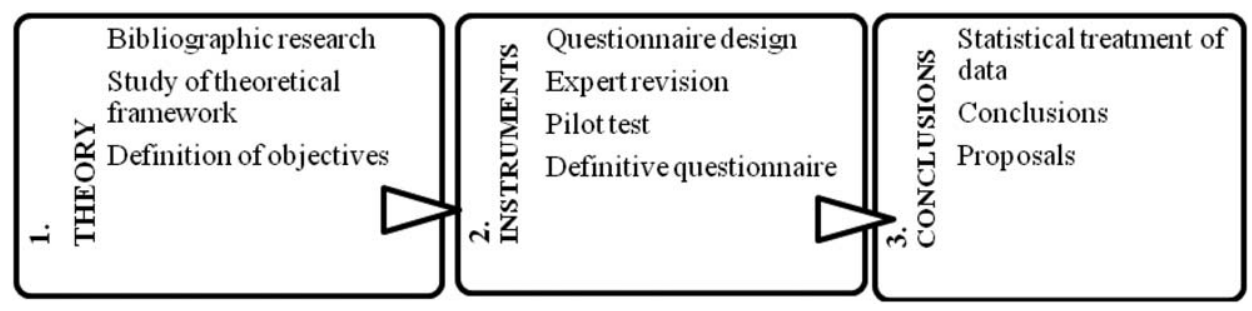

Figure 1: Phases of the study.

Source: authors.

of continuing education in institutions of higher education. The steps followed in the performance of these interviews have been:

1. Documentation: we developed the theoretical framework of the topic of the quest to know it thoroughly.

2. Script: we create an open script so that each interviewee could perform all the contributions deemed appropriate on the subject of study. This scenario was used to keep focused in the research topic.

3. Execution: to carry out the interviews we connected personally with each of the nine interviewees. We informed them about the subject of the search and we arranged an appointment in order to do the interview, moving to the place where they considered appropriate.

We developed the initial questionnaire after completing the study of the theoretical framework and performing in-depth interviews with experts in lifelong learning. They enabled us to define the dimensions that are related to the need for lifelong learning used in this study. These dimensions are: motivations; conflicts/difficulties; and career development.

The motivations dimension is common to many studies. Findlay et al. (2012) obtained a correlation between the desires to embark on training and increases in income. Using data from the Adult Education Survey, Boateng (2009) showed that the main motivation for 43 per cent of the respondents was to improve or change jobs and 21 per cent started training because of pressure from their employer. Facteau et al. (1995) found that motivation and imposition have an inverse relationship for training. Naquin and Holton (2003) concluded that work commitment is a key part of the motivation for pursuing training related to employment. Noe (1986), Noe et al. (2010) and Pastor et al. (2011) stressed the importance of understanding the user's training needs in this motivation. Sarfati (2013) noted that training favours the creation and continuance of jobs.

The conflicts/difficulties dimension is present in studies of several authors including Kyndt et al. (2011) who found that one of the major obstacles for older workers was a fear of 'going back to school' and that lack of time was an obstacle for younger workers. Brunet and Rodríguez-Soler (2014), Farías and Sevilla (2015), Marhuenda et al. (2010), Mayhew et al. (2008) and Natile (2013) stressed the problem of the level of initial training. Noe (1986) and Rigby and Ponce Sanz (2016) considered the fact that students may see objectives as unattainable a major challenge. Tabuenca et al. (2013) stressed lack of time as a major difficulty.

The career development dimension is also studied by various authors, including Arulampalam et al. (2004), Findlay et al. (2012) and Martin et al. (2013) who argued that the type of company is a determining factor in providing employees access to training. Busemeyer et al. (2012) empirically demonstrated that the amount of training a company offers to its employees is directly related to its size. Mamaqi et al. (2010) and Mamaqi and Miguel (2011) showed empirical evidence that training programmes agreed between the worker and the organization which are based on experience and capabilities can help to improve the stability and permanence of 
the employee in the company. Nuñez-Cacho et al. (2015) showed that coaching processes are an important tool for improving the individual-level of performance of human resources. Furthermore, the companies can benefit from the resulting effects on organizational performance, sales increase and productivity growth. Noe et al. (2010) observed that an organization that helps employees to obtain training, makes a positive influence on the demand for training and also better attracts and retains employees in key positions. Paracha et al. (2014) showed that training programs enhance employee skills and abilities such that they become more productive workers, in addition the company becomes more productive and training a serves a latent function of disseminating the worthiness of the employees in front of the organization and these employees, in turn, show a greater commitment to the organization.

Then, we developed an initial questionnaire, which has been validated in two ways: an experts' trial and a pilot test.

The first part was carried out by 21 experts from different and complementary institutions and backgrounds with wide and proven experience in training. The evaluations were performed in personal meetings or via email.

Each expert assessed three criteria for each of the items in the questionnaire:

- Univocally: is asked to evaluate the formal aspect of the item, that is, if it is understandable, if it is ambiguous and may lead to confusion or if it should be expressed in a different form. In short the experts should consider if the item in the question was or was not univocal. (Yes/No)

- Pertinence: the evaluation was a scale from 1 to 4 shall estimate the suitability of the item for the purpose of evaluation.

- Importance: it was evaluate with a scale from 1 to 4 shall assessed the significance of the item for the object of study.

The analysis of the results of the experts' trial we checked the validity of the content, through the study of the assessments, both for items and for judges. We calculated the Cronbach's alpha, the box diagrams (box-plot) and Tukey hinges among others.

The conclusions obtained as a result of expert's trial, allowed us to make relevant changes in the first questionnaire and got the second questionnaire that we submitted to a pilot test.

The pilot test was conducted by students of lifelong learning at the University of Andorra. The obtained sample was up of 52 questionnaires.

To evaluate the results of the pilot project we implemented a database, in order to the transform and validate the items. In order to avoid errors and inconsistency of the results we accorded to follow this criteria: verification of the nonexistence of missing, values out of range and invalid categories; incorrect values recoding in the database.

The pilot test enabled us to check the reliability of the instrument, as well as the internal consistency and construct validity. We calculated the value of Cronbach's alpha and obtain a value of 0.803 for the categorized values which is acceptable. We also made an exploratory factor analysis and we get the same factors that emerged from the literature review (Sabrià et al., 2012).

After the analysis of the results and appropriate changes were made, we arrived at the final questionnaire, which was to be validated. The steps in the validation of the questionnaire are displayed in Figure 2.

The results of the survey and the implementation of the proposed model were analysed using the SPSS program, and we used the AMOS and EQS program for confirmatory factor analysis. All indicators of the model were measured using a 5-point Likert scale, where 0 was the weakest or disagreement and 4 the strongest degree or complete agreement. An overview of the study is shown in Table 2.

Once the data was gathered we followed this methodological process:

I. Steps prior to developing models 
Population

Instrument

Sample size

Confidence level

Variance

Maximum error
Lifelong learners from Andorra and Spain (courses of at least 6 ECTS)

Questionnaire distributed on paper

812 valid surveys

$95 \%$

0.25 (maximum possible value)

$\pm 3.4 \%$

a. Exploratory data analysis

b. Exploratory factor analysis (EFA). Obtain factors

c. Evaluation of confirmatory factor analysis (CFA)

II. Development and evaluation of model

The results of Point 1 have been included in the methodology section because they are steps prior to the development of the model (which we considered the primary outcome of this study).

\section{Exploratory data analysis}

The sample was composed of 45 per cent men and 55 per cent women. The mean age was 34 years with a standard deviation of 13. Age distribution was similar for both sexes. The average number of years of work experience was 11 with a standard deviation of 9 .

Some 83 per cent of people in the sample were university graduates; 12 per cent were full-time students; 14 per cent were unemployed; and 74 per cent were employed. Of the active individuals 23 per cent worked in the state sector, 70 per cent in private industry and 7 per cent were self-employed.

The data did not meet the condition of univariate and multivariate normality, and so the techniques used to estimate the parameters were: the weighted least squares method (Rial et al., 2006); and the robust standard estimator method (Bou \& Satorra, 2010; Satorra, 1990, 2002; Satorra \& Bentler, 2010).

Models were estimated with both methods and using the AMOS software and EQS.

\section{Exploratory factor analysis}

The literature review found no theoretical model or hypothesis supported by theory which enables a determination of which observable variables contribute to directly measuring latent variables or constructs that define each dimension. In this case, following the Lévy Mangin et al. (2006) criteria, an EFA was calculated as a preliminary step before exploration.

Before performing this step, we considered the existence of a correlation between variables, but as there were no common factors it would make no sense to do this for each dimension. We made the assessment using Bartlett's test of sphericity and the Kaiser-Meyer statistic-Okin. The value found oscillated between 0 and 1 , and for values greater than 0.5 the use of the data factor model is considered acceptable (Kaiser, 1974; Perez, 2009).

Initially, we took into account all the variables that could influence each of the dimensions (as detailed in the literature review). Based on the results obtained we respecified the analysis. The final results for each dimension follow below:

Motivation dimension (Figure 3)

Conflicts/difficulties dimension (Figure 4)

Career development dimension (Figure 5) 


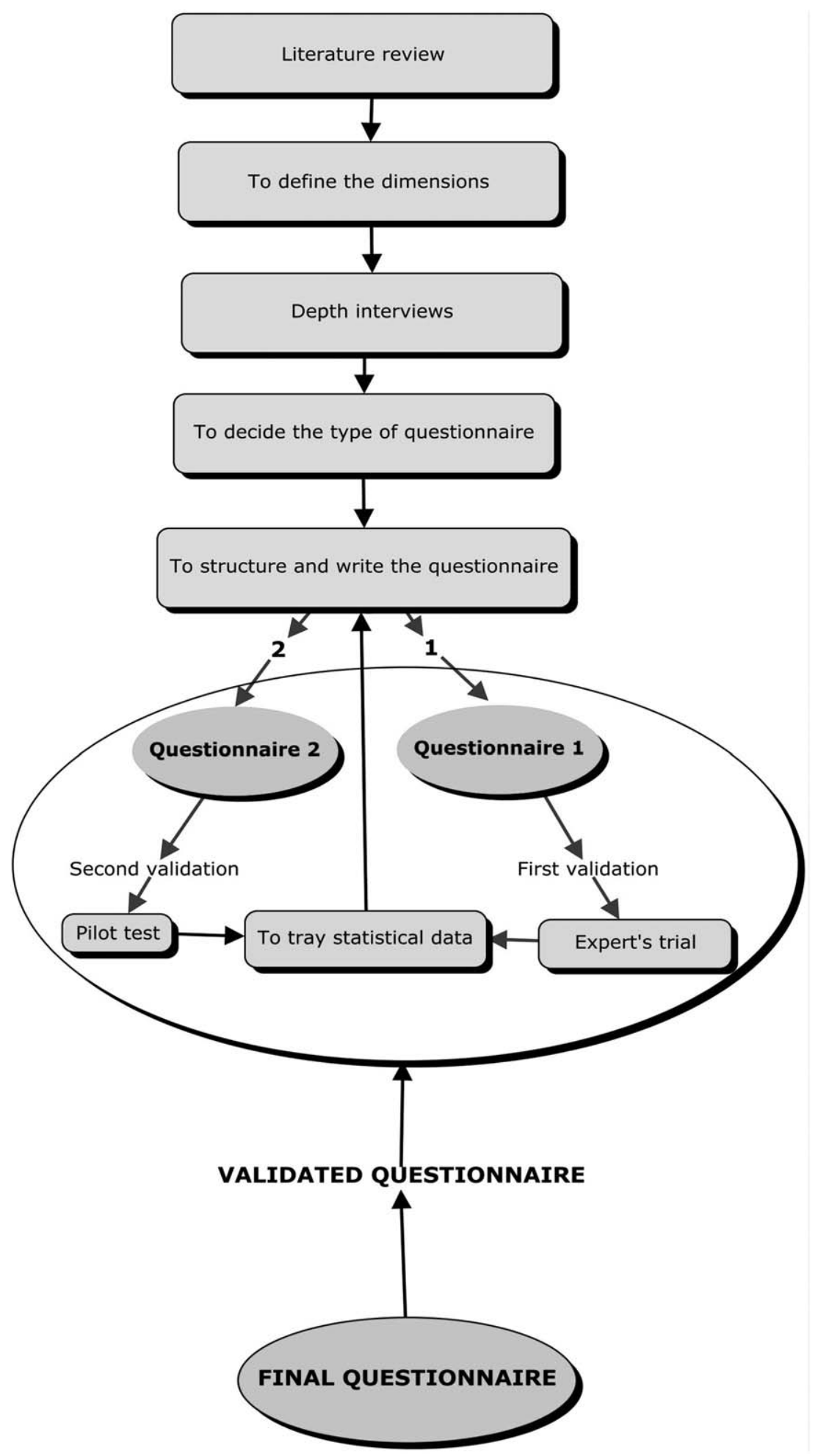

Figure 2: Validation of the questionnaire. Source: authors. 


\begin{tabular}{|c|c|}
\hline $\begin{array}{l}\text { current job } \\
\text { factor }\end{array}$ & $\begin{array}{l}\cdot \text { Maintain job }(0,796) \\
\text { - Reduce the chance of losing job }(0,699) \\
\text { - Company imposition or requirement }(0,608)\end{array}$ \\
\hline $\begin{array}{l}\text { career change } \\
\text { factor }\end{array}$ & $\begin{array}{l}\text { - Improve chance of earning more }(0,568) \\
\text { - Improve chance of changing job }(0,956)\end{array}$ \\
\hline $\begin{array}{l}\text { pesonal development } \\
\text { factor }\end{array}$ & $\begin{array}{c}\cdot \text { Improveskills }(0,744) \\
\cdot \text { Heighten personal development }(0,695) \\
\cdot \text { Updateknowledge }(0,678)\end{array}$ \\
\hline
\end{tabular}

Figure 3: Results of exploratory factor analysis on the motivation dimension. Source: authors.

\begin{tabular}{|c|c|}
\hline $\begin{array}{l}\text { personal } \\
\text { factor }\end{array}$ & $\begin{array}{l}\text { - Little desire to study again }(0,752) \\
\text { - Training objectives difficult }(0,738) \\
\text { - Age or health }(0.674) \\
\text { - Insufficient initial education }(0,554) \\
\text { - Content does not meet needs }(0,496)\end{array}$ \\
\hline $\begin{array}{l}\text { external } \\
\text { factor }\end{array}$ & $\begin{array}{l}\text { - No nearby offer }(0,743) \\
\text { - Difficulty in reaching centre }(0,702) \\
\text { - Cost }(0,691)\end{array}$ \\
\hline $\begin{array}{c}\text { time } \\
\text { factor }\end{array}$ & $\begin{array}{l}\text { - Lack of time }(0,708) \\
\text { - Family responsibilities }(0,706) \\
\text { - Incompatible working hours }(0,584)\end{array}$ \\
\hline
\end{tabular}

Figure 4: Results of exploratory factor analysis on the conflicts/difficulties dimension. Source: authors.

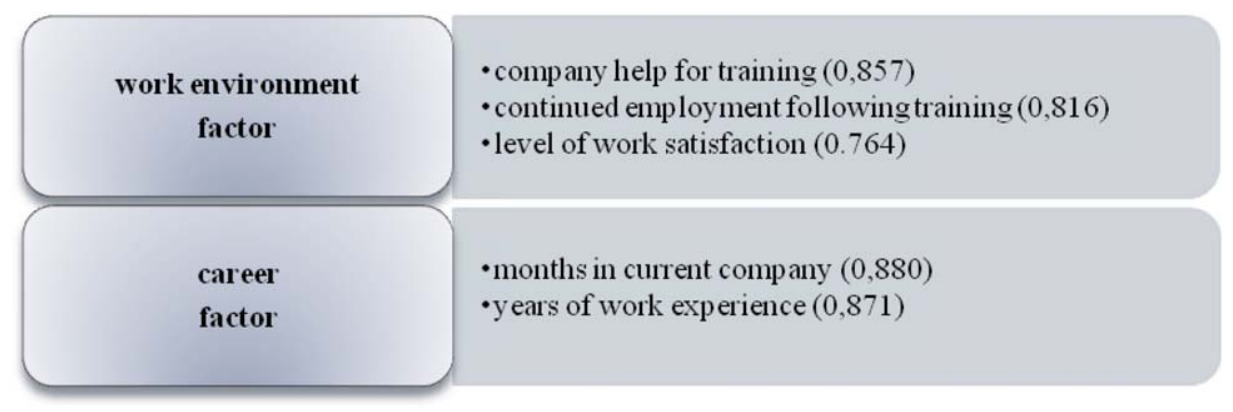

Figure 5: Results of exploratory factor analysis for career development dimension. Source: authors.

\section{Confirmatory factor analysis}

With the factors obtained, we performed a confirmatory factor analysis for each of the dimensions to check the validity of the model. First, we analysed the overall fit of the model by employing:

- Goodness of fit to determine the extent to which the model predicts the initial data matrix with indices: McDonald's (MFI) and root mean square error of approximation. 
- Incremental setting to compare the proposed model with a null reference model which states that there is no relationship between the variables with the following indices: normed fit index which measures the proportional reduction in the adjustment function on changing the null model for the proposed model; the non-normed fit index or Tucker Lewis index compares the degree of freedom adjustment between the null model and proposed model; the incremental fit index is similar to the previous index but does not take the degrees of freedom into account, and the comparative fit index which is valid for large samples and compares the maximum values of the $\chi^{2}$ setting and the degrees of freedom between the proposed model and the null index.

- The parsimonious setting to examine the degree to which each setting was reached for each coefficient or estimated parameter with the indices chi-square $\chi^{2}$ statistic (which measures the distance between the data matrix and that which estimates the model), and the normed chi-square which is very suitable for large samples.

Below we study the analysed measurement model setting:

- The unidimensionality of each of the latent variables or factors performing an EFA for each factor.

- The composite reliability of observable variable, indicating the degree to which the indicators or observable variables fit the factor. Checks have been made by studying the statistical significance between each factor and indicator; and the individual reliability of each item using standardized item loads with each factor.

- The internal consistency of the analysed indicators: the composite reliability, extracted variance, as well as convergent and discriminant validity.

\section{Motivations dimension}

A model was initially proposed in which each latent variable or factor was associated with observable variables given in the EFA. This model produced some indices outside the reference values and it was considered appropriate to make modifications. These were achieved using the modification index (MI) of the AMOS program and Lagrange modification test (LMTest) in the EQS program. Both the MI as well as LMTest showed that the model improved if the following variable was associated: reduce the possibility of job being lost with the career development construct. For this reason, we proposed the model shown in Figure 6, which was validated by theCFA.

\section{Conflicts/difficulties dimension}

We followed the same procedure as in the case of motivations dimension and we proposed the model shown in Figure 7, which was validated by the CFA.

\section{Career development dimension}

The proposed model, Figure 8, coincides with that obtained in the EFA and results of which was validated by the CFA.

\section{Results}

The structural model for each of the dimensions has involved the introduction of an exogenous latent variable of an order higher than the dimension. This new variable brings together all the top-level factors. The factors integrated in the CFA become endogenous latent variables and the exogenous latent variable is the higher order factor.

After checking the measurement model for each of the dimensions we proceeded to check the structural model that establishes the causal relationships between constructs. We made the evaluation by checking the second-level factor loadings and the proportion of variance explained by the latent variable. 


\section{Motivations dimension}

The proposed model for the motivations dimension is shown in Figure 9.

The matrix expression of the results obtained with MLrobust estimation is shown below.

$$
\left(\begin{array}{c}
\text { maintain job } \\
\text { company imposition } \\
\text { fear of job loss } \\
\text { get or change job } \\
\text { earn more } \\
\text { heighten development } \\
\text { improve skills } \\
\text { update knowledge }
\end{array}\right)=\left(\begin{array}{ccc}
0.860 & 0.000 & 0.000 \\
0.594 & 0.000 & 0.000 \\
0.605 & 0.291 & 0.000 \\
0.000 & 0.940 & 0.000 \\
0.000 & 0.670 & 0.000 \\
0.000 & 0.000 & 0.703 \\
0.000 & 0.000 & 0.749 \\
0.000 & 0.000 & 0.648
\end{array}\right) *\left(\begin{array}{c}
\text { current job } \\
\text { career change } \\
\text { personal development }
\end{array}\right)+\left(\begin{array}{l}
0.269 \\
0.647 \\
0.350 \\
0.116 \\
0.551 \\
0.506 \\
0.439 \\
0.580
\end{array}\right)
$$

\section{Conflict/difficulties dimension}

The proposed conflicts/difficulties are shown in Figure 10.

The matrix expression of the results obtained with MLrobust estimation is shown below.

\section{MLrobust}

$$
\left.\begin{array}{c}
\left(\begin{array}{c}
\text { objectives difficult } \\
\text { desire study } \\
\text { age or health } \\
\text { initial education } \\
\text { family responsabilities } \\
\text { hours of training } \\
\text { lack of time } \\
\text { difficulty moving } \\
\text { no nearby offer } \\
\text { cost } \\
\left(\begin{array}{c}
\text { personal } \\
\text { time } \\
\text { external }
\end{array}\right)
\end{array}\right)=\left(\begin{array}{ccc}
0.713 & 0.000 & 0.000 \\
0.740 & 0.000 & 0.000 \\
0.718 & 0.000 & 0.000 \\
0.626 & 0.000 & 0.000 \\
0.000 & 0.721 & 0.000 \\
0.000 & 0.636 & 0.000 \\
0.000 & 0.698 & 0.000 \\
0.000 & 0.000 & 0.781 \\
0.000 & 0.000 & 0.761 \\
0.000 & 0.000 & 0.682
\end{array}\right) *\left(\begin{array}{c}
0.492 \\
\text { time } \\
\text { external }
\end{array}\right)+\left(\begin{array}{c}
0.452 \\
0.484 \\
0.608 \\
0.480 \\
0.596 \\
0.390 \\
0.390 \\
0.465 \\
0.671
\end{array}\right) *(\text { conflicts/difficulties })+\left(\begin{array}{l}
0.601 \\
0.681 \\
0.550
\end{array}\right) \\
0.535
\end{array}\right)
$$




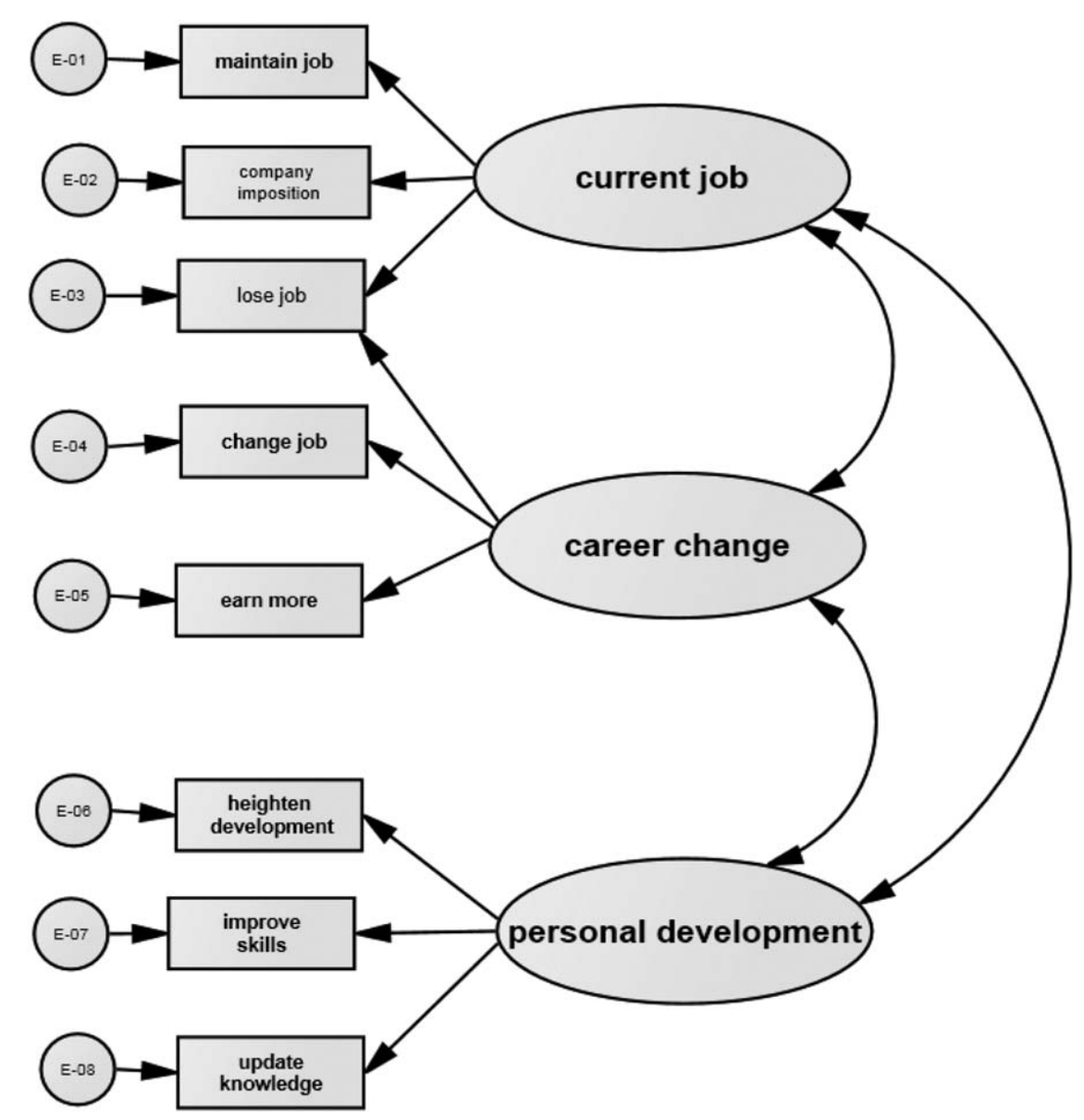

Figure 6: Model of CFA for motivations dimension.

Source: authors.

\section{Career development dimension}

The proposed conflicts/difficulties dimension is shown in Figure 11.

The matrix expression of the results obtained with MLrobust estimation is shown below.

$$
\left(\begin{array}{c}
\text { years work experience } \\
\text { months in current company } \\
\text { company help for training } \\
\text { work satisfaction } \\
\left(\begin{array}{c}
\text { professional experience } \\
\text { work environment }
\end{array}\right)
\end{array}\right)=\left(\begin{array}{cc}
1.000 & 0.000 \\
0.602 & 0.000 \\
0.000 & 0.828 \\
0.000 & 0.603 \\
0.000 & 0.687
\end{array}\right) *\left(\begin{array}{l}
0.133 \\
\text { work environment }
\end{array}\right) *(\text { career development })+\left(\begin{array}{l}
0.982 \\
0.726
\end{array}\right)+\left(\begin{array}{l}
0.000 \\
0.473
\end{array}\right)\left(\begin{array}{c}
0.638 \\
0.314 \\
0.528
\end{array}\right)
$$




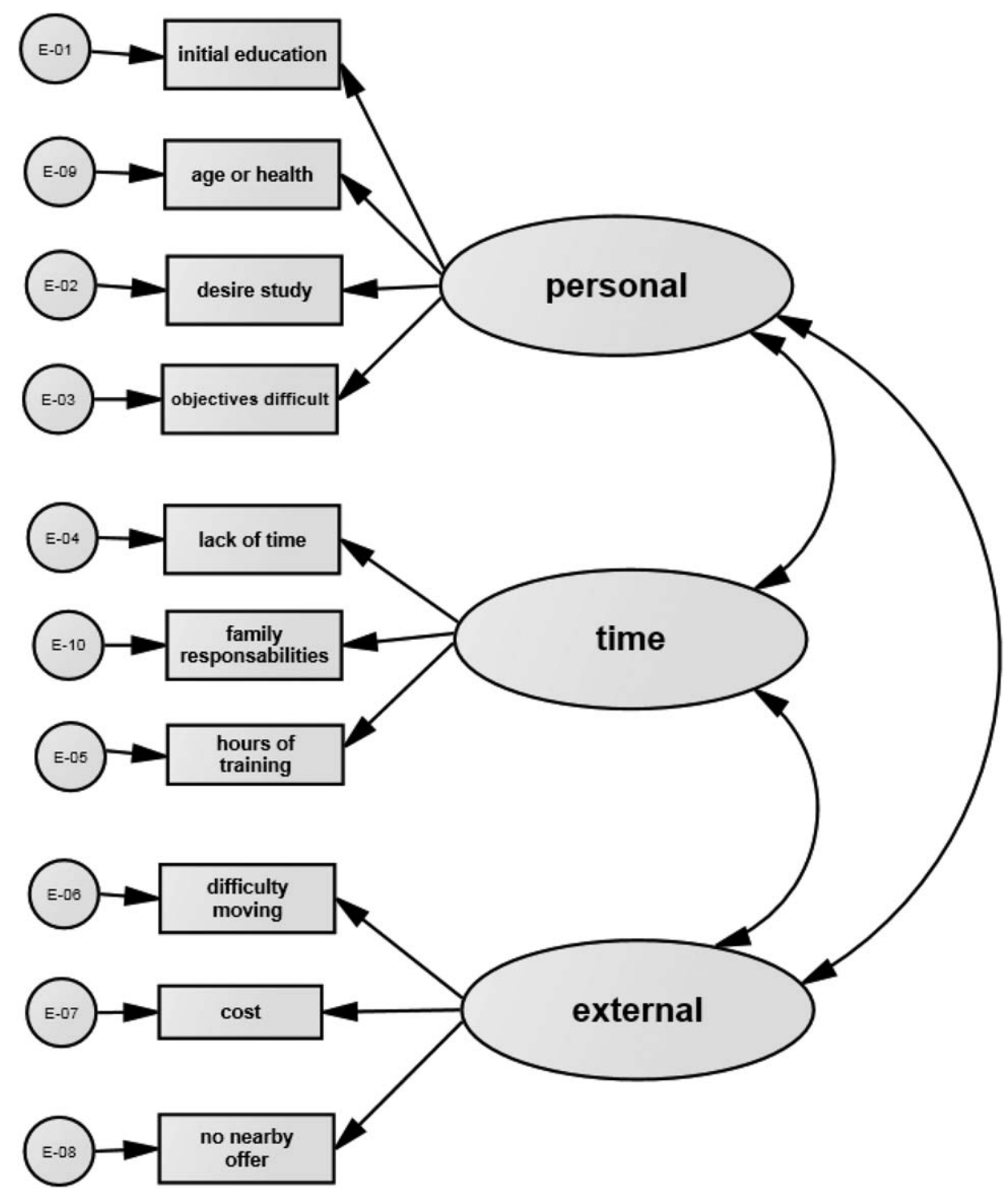

Figure 7: Model of CFA for conflicts/difficulties dimension.

Source: authors.

\section{Discussion and conclusion}

The aim of this study was to obtain the determinants of the demand for lifelong learning in institutions of higher education. Most studies address the demand for lifelong learning from the perspective of the organization and empirical evidence is not usually obtained after a literature review and the performance of in-depth interviews experts in lifelong learning, we obtained the three dimensions in which the study is based: motivations, conflicts/difficulties and career development. Then, we validated a questionnaire using expert opinion and a pilot test that we distributed to students of continuous formation of institutions of higher education. The treatment of the 812 questionnaires of the sample was performed using statistical univariates, multivariates and modelling with structures of covariance structures or structural equations using two methods of estimation: asymptotically distribution-free (ADF) and robust maximum likelihood (MLrobust). 


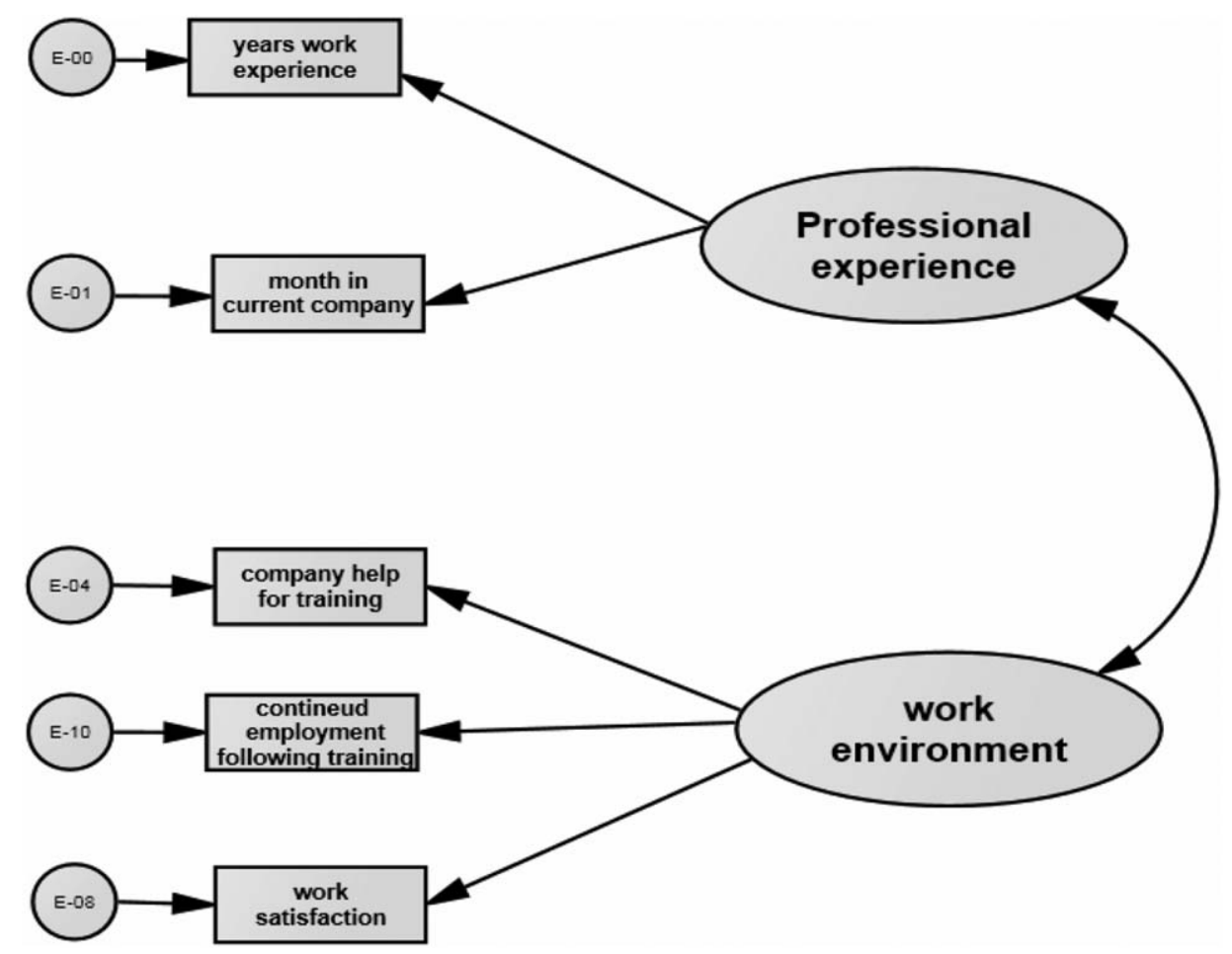

Figure 8: Model of CFA for career development dimension. Source: authors.

The conclusions of this work for each of the extracted dimensions are given below ${ }^{1}$ :

\section{- $\quad$ MOTIVATIONS dimension}

The dependent factors in the motivations dimension are: career change, current work and personal development. The career change factor depends on the observed variables: get/change jobs, obtain higher pay and decrease the likelihood of losing job. Current work factor depends on: maintaining employment, fear of losing job and undertake training according to needs of the company. The personal development factor depends on: improving skills, increase personal development and update knowledge. These results agree with previous studies e.g. Boateng (2009) with data from an adult education survey indicated that 43 per cent of respondents conducted lifelong learning for professional career development, and 21 per cent by imposition of the company. Noe (1986) and Johnson and Beehr (2014) indicated that motivation to learn is related to the workplace and improving skills. Findlay et al. (2012) obtained correlation between the desire to train and earn more.

- CONFLICTS/DIFFICULTIES dimension

The dependent factors in this dimension are: personal, time-related and external. The personal factor depends on the observed variables: little desire to go back to school, age or health, problems in reaching training objectives, lack of offer nearby and lack of initial training. The time factor depends on: family responsibilities, time available to study and training hours. The external factor depends on: difficulty in mobility; lack of nearby supply; and economic costs. These results agree

${ }^{1}$ The factors and variables extracted depend on each being ranked from greatest to least lineal dependence. 


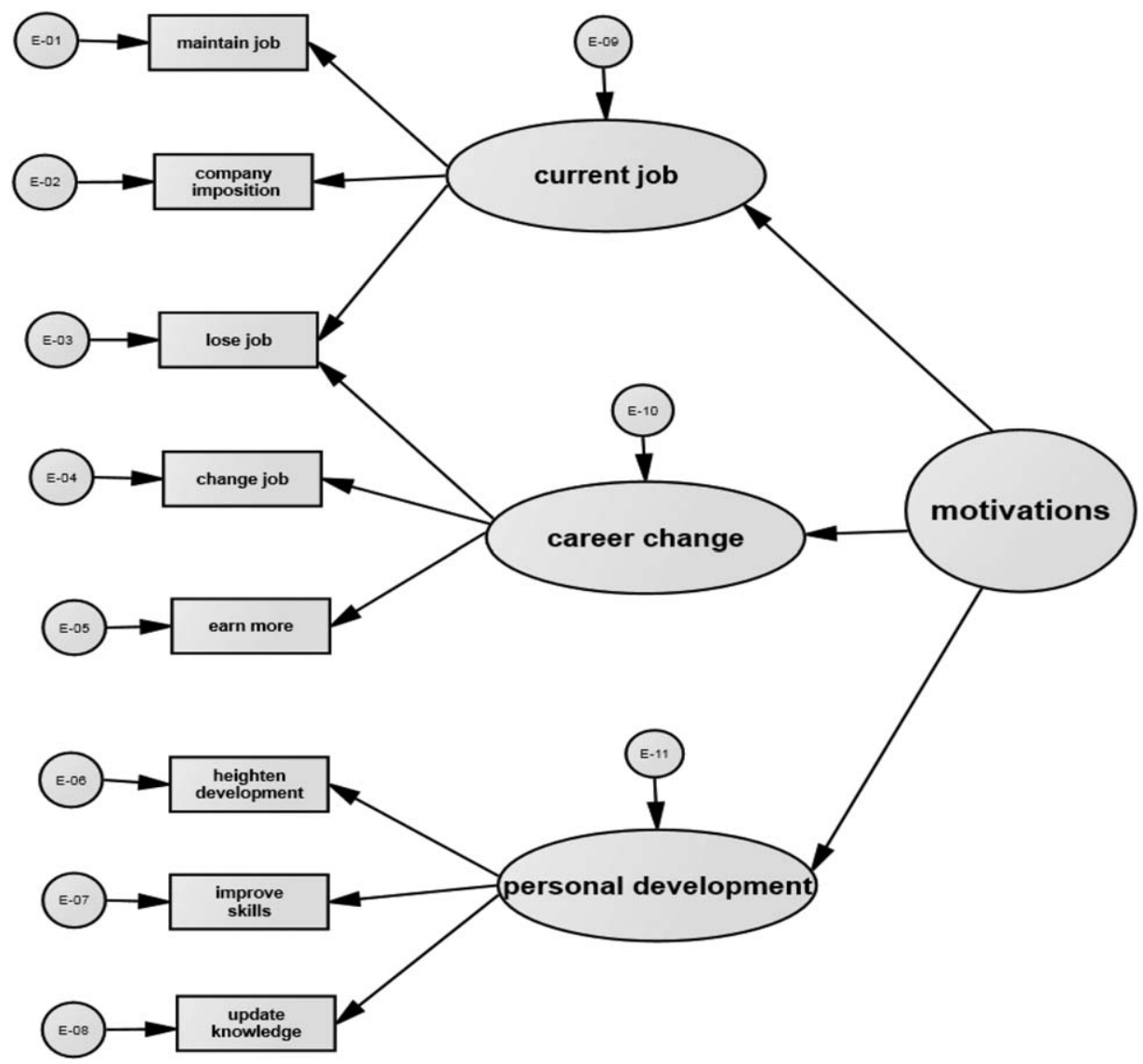

Figure 9: Model of motivationsdimension.

Source: authors.

with previous studies: Brown and Charlier (2013) highlighted difficulty in reaching the place where training is offered; Tabuenca et al. (2013) found that the main difficulty for lifelong learners was finding a suitable time for training; Kyndt et al. (2011) found that one of the most important obstacles for older workers was 'fear of going back to school' and for younger workers it was finding the time for training.

- CAREER DEVELOPMENT dimension

The dependent factors for the dimension are: work environment and work experience. Work environment depends on: years of experience and months spent working in the current company. The working environment factor depends on: company facilities for training, continued employment if training is facilitated and job satisfaction. These results agree with previous studies: Fajar and Hidajat (2012) remarked that the most valuable asset for organizations is the knowledge and skills of its workers and related productivity; Mamaqi and Miguel (2011) and Mamaqi et al. (2010) obtained empirical evidence that specific training for employees helps improve the stability and permanence of the employee in the company. Fugate et al. (2004) stated that individuals who adapt their knowledge and behaviour increase their employability. Guerrazzi (2016) remarked an increase in the percentage of trained workers and the average hours of training per worker may increase the impact of training on productivity.

Coinciding with the initial intention of providing new knowledge in this field that may be useful for institutions of higher education and other agents of the system when 


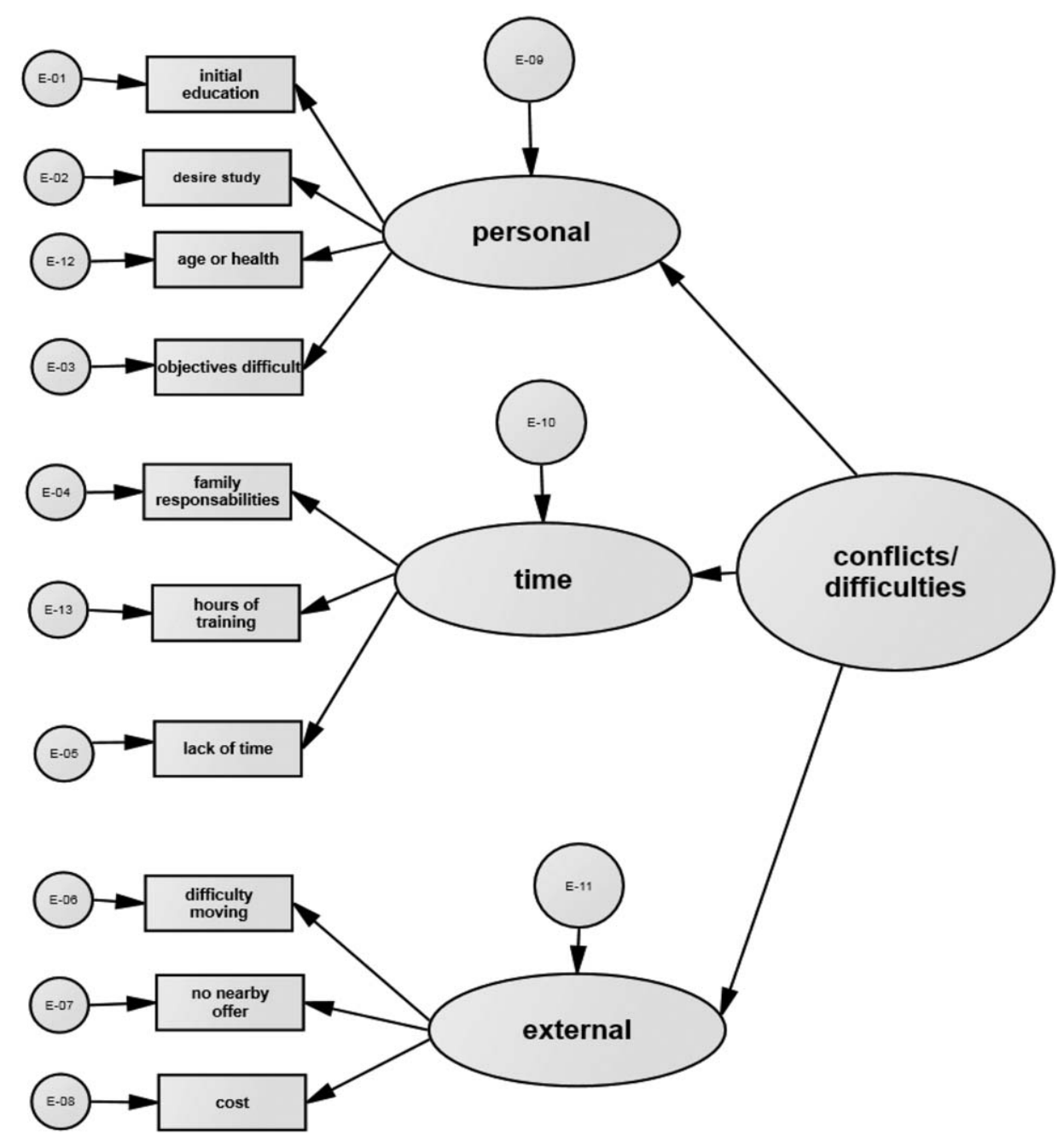

Figure 10: Model of conflicts/difficulties dimension.

Source: authors.

designing new training programmes, the results have enabled us to extract a typical profile of people demanding lifelong learning and recommendations for offering such training.

\section{Implications for institutions of higher education}

Given that the main motivation is career change, institutions of higher education should offer training that provides the skills sought by potential students and then grant supporting academic certificates. To overcome conflicts/difficulties, institutions should carefully specify the requirements for admission; offer courses tailored to the demanding schedules of students and perhaps encourage blended learning. At the same time, institutions could adjust the maximum price of courses, provide scholarships and find sponsors (albeit a difficult task in the current economic crisis).

\section{Implications for organizations more generally}

Organizations should have a well-defined career for their employees, enable career change and offer job security. Organizations could help overcome the conflicts/ 


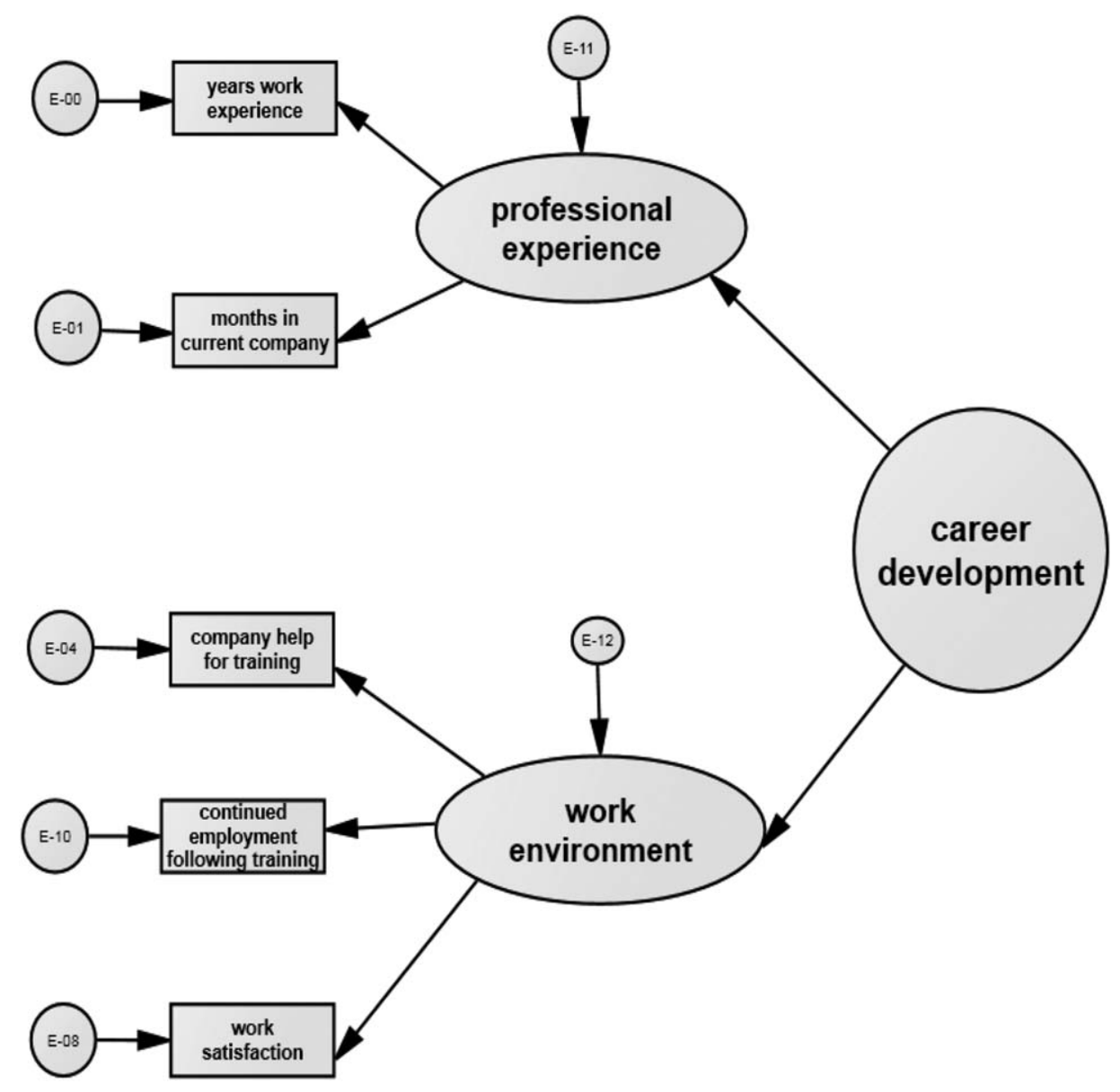

Figure 11: Model of career development dimension.

Source: authors.

difficulties associated with time factors by offering flexible schedules and reconciling work and family life. Workers positively value the opportunity to train and this facilitates a climate of job satisfaction.

\section{Implications for potential students}

Lifelong training is the best investment a person can make. It is a key factor in a career, as well as helping to cover the deficiencies of formal education and updating acquired skills. A lack of initial training and the fear of not achieving the objectives are major obstacles when individuals consider starting a training course. However, it should be mentioned that a large percentage of the population has no accreditation of their work skills. It is important that everyone is aware of their own skills and recycles work experience and training in their work activity. The difficulties related to time are also important and a possible solution would be to opt for the blended learning mode.

A pro-active attitude to work generally results in a need to learn. By performing the same task in the same way without any changes or revision, a person can spend many years in organization without acquiring any significant professional experience. Similarly, if a person experiences - even for a short period of time - different work situations that involve recycling and learning, they may be able to provide value added professional skills quickly after joining an organization. 
We think the main contributions of this work are; the validation of a questionnaire to obtain the determinants of the demand for lifelong learning in Institutions of Higher Education, and empirical evidence for these determinants from the perspective of people who seek training.

The results of this study may help in developing the following criteria:

- knowledge - by providing cognition, data and empirical evidence of demand for continuing education from the perspective of the user. As it has been explained in literature review only a few studies address this issue from the perspective of user training and very few studies have obtained empirical evidence of their results

- development - involving the user reflecting on their professional studies, as well as their motivations and difficulties; the results obtained consist a useful tool for designing future training.

- advance - intended to detect the determinants of demand so that future training can anticipate factors that may influence training proposals.

\section{Limitations and future work}

This study uses structural equation modelling (SEM) to adjust the model to the data. From the statistical point of view, we can say that the presented models belong to the family of alternative models that are compatible with the data and valid from an empirical perspective. Bollen (1989) explained one of the limitations of using SEM: 'If a model is consistent with reality, the data should be consistent with the model. But if the data is consistent with the model that does not mean that the model matches reality' (p. 68). A strong point of this study is the fact that the validity of the models has been checked using the ADF and MLrobust estimation techniques.

An improvement to this study would be a revision of the questionnaire by introducing new variables for the direct measurement of user demand for lifelong learning to enable an amplification of the structural model with new variables that bear directly on the latent variable demand.

\section{References}

Aragón, A., Barba, I. and Sanz, R. (2003), 'Effects of training on business results', International Journal of Human Resource Management, 14, 6, 956-80.

Arulampalam, W., Booth, A. L. and Bryan, M. L. (2004), 'Training in Europe', Journal of the European Economic Association, 2, 3, 346-60.

Ballot, G., Fakhfakh, F. and Taymaz, E. (2006), 'Who benefits from training and R\&D, the firm or the workers?', British Journal of Industrial Relations, 44, 3, 473-95.

Barrett, A. and O'connell, P. J. (2001), 'Does training generally work? The returns to in-company training', Industrial and Labor Relations Review, 54, 3, 647-62.

Bartel, A. P. (1994), 'Productivity gains from the implementation of employee training programs', Industrial Relations: A Journal of Economy and Society, 33, 4, 411-25.

Bartel, A. P. (2000), 'Measuring the employer's return on investments in training: evidence from the literature', Industrial Relations: A Journal of Economy and Society, 39, 3, 502-24.

Bassi, L. J., Ludwig, J., McMurrer, D. and Van Buren, M. (2002), 'Profiting from learning: firmlevel effects of training investments and market implications', Singapore Management Review, 24, 3, 61-76.

Birdi, K., Clegg, C., Patterson, M., Robinson, A., Stride, C. B., Wall, T. D. and Wood, S. (2008), 'The impact of human resource and operational management practices on company productivity: a longitudinal study', Personnel Psychology, 61, 3, 467-501.

Black, S. E. and Lynch, L. M. (1996), 'Human-capital investments and productivity', American Economic Review, 86, 2, 263-7.

Boateng, S. K. (2009). Significant Country Differences in Adult Learning (Eurostat: Statistics in Focus).

Bollen, K. A. (1989). Structural Equations with Latent Variables (New York: Wiley).

Bou, J. C. and Satorra, A. (2010), 'A multigroup structural equation approach: a demonstration by testing variation of firm profitability across EU samples', Organizational Research Methods, 13, 4, 738-66. 
Brown, K. G. and Charlier, S. D. (2013), 'An integrative model of e-learning use: leveraging theory to understand and increase usage', Human Resource Management Review, 23, 1, 37-49.

Brunet, I. and Rodríguez-Soler, J. (2014), 'Formación profesional e innovación: estudio de la transferencia de innovación entre centros de FP y empresas', Revista De Educación, 365, 177-201.

Busemeyer, M. R., Neubäumer, R., Pfeifer, H. and Wenzelmann, F. (2012), 'The transformation of the German vocational training regime: evidence from firms' training behaviour', Industrial Relations Journal, 43, 6, 572-91.

Chu-Ng, Y. (2005), 'Training determinants and productivity impact of training in China: a case of Shanghai', Economics of Education Review, 24, 3, 275-95.

Commission of the European Communities. (2000), 'A memorandum on lifelong learning', SEC Brussels, 1832, 1-36.

Danvila, I. and Sastre, M. A. (2009), 'El papel de la formación de personal en el proceso e implantación de un sistema de calidad total', Contaduría y Administración, 222, 9-20.

Dearden, L., Reed, H. and Van Reenen, J. (2006), 'The impact of training on productivity and wages: evidence from British panel data', Oxford Bulletin of Economics and Statistics, 68, 4, 397-421.

De Grip, A. and Sauermann, J. (2013), 'The effect of training on productivity: the transfer of onthe-job training from the perspective of economics', Educational Research Review, 8, 28-36.

Delery, J. E. and Doty, D. H. (1996), 'Modes of theorizing in strategic human resource management: tests of universalistic, contingency, and configurational performance predictions', Academy of Management Journal, 39, 4, 802-35.

Delmas, M. A. and Pekovic, S. (2013), 'Environmental standards and labor productivity: understanding the mechanisms that sustain sustainability', Journal of Organizational Behavior, 34, 2, 230-52.

Eguiguren-Huerta, M., Llinàs-Audet, X. and Pons-Peregort, O. (2006), 'In-company training in Catalonia: organizational structure, funding, evaluation and economic impact', International Journal of Training and Development, 10, 2, 140-163.

European Council. (2000). European Council Lisboa 23 and 24 March 2000. Conclusions of the Presidency. Newsletter of the European Union, 3-2000.

European Parliament and Council. (2006a), 'Recommendation of the European Parliament and the Council of 18 December 2006 on key competencies for lifelong learning', Official Journal of the European Union, 30, 12, 2006.

European Parliament and Council. (2006b), 'November Decision no. 1720/2006/CE', Diario Oficial de la Unión Europea, L327, 45-68.

Eurydice Network. (2011). 'Adults in formal education: policies and practice in Europe', Brussels: Education, Audiovisual and Culture Executive Agency. Available at: http://eacea.ec. europa.eu/education/eurydice/documents/thematic_reports/128EN.pdf (accessed July 19, 2012).

Facteau, J. D., Dobbins, G. H., Russell, J. E. A., Ladd, R. T. and Kudisch, J. D. (1995), 'The influence of general perceptions of the training environment on pretraining motivation and perceived training transfer', Journal of Management, 21, 1, 1-25.

Fajar, A. and Hidajat, J. (2012), 'Relationship among soft skills, hard skills, and innovativeness of knowledge workers in the knowledge economy era', Procedia Social and Behavioral Sciences, 52, 35-44.

Farías, M. and Sevilla, M. P. (2015), 'Effectiveness of vocational high schools in students' access to and persistence in postsecondary vocational education', Research in Higher Education, 56, 7, 693-718.

Findlay, J., Findlay, P. and Warhurst, C. (2012), 'What every worker wants? Evidence about employee demand for learning', British Educational Research Journal, 38, 3, 515-32.

Fugate, M., Kinicki, A. J. and Ashforth, B. E. (2004), 'Employability: a psycho-social construct, its dimensions, and applications', Journal of Vocational Behavior, 65, 1, 14-38.

Govaerts, N. and Dochy, F. (2014), 'Disentangling the role of the supervisor in transfer of training', Educational Research Review, 12, 77-93.

Govaerts, N., Kyndt, E., Dochy, F. and Baert, H. (2011), 'Influence of learning and working climate on the retention of talented employees', Journal of Workplace Learning, 23, 1, 35-55.

Guerrazzi, M. (2016), 'The effect of training on Italian firms' productivity: microeconomic and macroeconomic perspectives', International Journal of Training and Development, 20, 1, 38-57.

Huselid, M. A. (1995), 'The impact of human resource management practices on turnover, productivity, and corporate financial performance', Academy of Management Journal, 38, 3, 635-72.

Huselid, M., Jackson, S. and Schuler, R. (1997), 'Technical and strategic human resource management effectiveness as determinants of firm performance', Academy of Management Journal, 40, $1,171-88$.

20 International Journal of Training and Development

(c) 2017 Brian Towers (BRITOW) and John Wiley \& Sons Ltd. 
Ichniowski, C. and Shaw, K. (1999), 'The effects of human resource management systems on economic performance: an international comparison of US and Japanese plants', Management Science, 45, 5, 704-21.

Idrus, H., Noor, A. M. and Baharom, M. N. R. (2012), 'Motivating engineering and technical students to learn technical writing by inculcating lifelong learning skills', International Journal of Learning, 18, 11, 191-202.

Janssens, L., Smet, K., Onghena, P. and Kyndt, E. (2016), 'The relationship between learning conditions in the workplace and informal learning outcomes: a study among police inspectors', International Journal of Training and Development, doi:10.1111/ijtd.12095

Johannessen, J. A. and Olsen, B. (2003), 'Knowledge management and sustainable competitive advantages: the impact of dynamic contextual training', International Journal of Information Management, 23, 4, 277-89.

Johnson, V. A. and Beehr, T. A. (2014), 'Making use of professional development: employee interests and motivational goal orientations', Journal of Vocational Behavior, 84, 2, 99-108.

Kaiser, H. F. (1974), 'An index of factorial simplicity', Psychometrika, 39, 1, 31-6.

Kazamaki, E. and Lindh, T. (1999), 'Evaluating firm training, effects on performance and labour demand', Applied Economics Letters, 6, 7, 431-7.

Kyndt, E., Michielsen, M., Van Nooten, L., Nijs, S. and Baert, H. (2011), 'Learning in the second half of the career: stimulating and prohibiting reasons for participation in formal learning activities', International Journal of Lifelong Education, 30, 5, 681-99.

Lévy Mangin, J., Varela Mallou, J. and Abad González, J. (2006). Modelización Con Estructuras De Covarianzas En Ciencias Sociales: temas Esenciales, Avanzados y Aportaciones Especiales (Oleiros: Netbiblo).

Maluti, L. V., Warentho, T. O. and Shiundu, J. O. (2012), 'Impact of employee commitment on retention in state financial corporations in Kenya', International Journal of Business and Public Management, 2, 2, 30-8.

Mamaqi, X. and Miguel, J. A. (2011), 'El perfil profesional de los formadores de formación continua en España', Relieve, 17, 1, 12-01-2012-1-32.

Mamaqi, X., Olave, P. and Miguel, J. (2010), 'Recruitment and rotation of the trainers in the lifelong learning context', in M. D. Lytras, P. Ordonez De Pablos, D. Avison, J. Sipior, Q. Jin, W. Leal Filho, L. Uden, M. Thomas, S. Cervai, and D. G. Horner, (eds) Technology Enhanced Learning: Quality of Teaching and Educational Reform, (Berlin: Springer), p. 694.

Marcelo, C. (2010). 'Autoformación para el siglo XXI', in J. Gairín (ed.), Nuevas Estrategias Formativas Para Las Organizaciones (Madrid: Wolters Kluwer), pp. 141-70.

Marhuenda, F., Bernad, J. C. and Navas, A. (2010), 'Las prácticas en empresa como estrategia de enseñanza e inserción laboral: las empresas de inserción social', Revista De Educación, 351, 139-61.

Martín, M., Rabadán, A. B. and Hernández, J. (2013), ‘Desajustes entre formación y empleo en el ámbito de las Enseñanzas Técnicas universitarias: la visión de los empleadores de la Comunidad de Madrid', Revista De Educación, 360, 244-67.

Mayhew, M. J., Wolniak, G. C. and Pascarella, E. T. (2008), 'How educational practices affect the development of life-long learning orientations in traditionally-aged undergraduate students', Research in Higher Education, 49, 4, 337-56.

Milanovic, B. (2011), 'Más o menos: la desigualdad del ingreso ha aumentado en los últimos 25 años, en lugar de disminuir como se habia previsto', Finanzas y Desarrollo: publicación Trimestral Del Fondo Monetario Internacional y Del Banco Mundial, 48, 3, 6-11.

Molina, J. A. and Ortega, R. (2003), 'Effects of employee training on the performance of NorthAmerican firms', Applied Economics Letters, 10, 9, 549-52.

Myers, M., Griffith, D., Daugherty, P. and Lusch, R. (2004), 'Maximizing the human capital equation in logistics: education, experience and skills', Journal of Business Logistic, 25, 1, 211-32.

Naquin, S. and Holton, E. (2002), 'The effects of personality, affectivity, and work commitment on motivation to improve work through learning', Human Resource Development Quarterly, 13, 4, 357-76.

Naquin, S. and Holton, E. (2003), 'Motivation to improve work through learning in human resource development', Human Resource Development International, 6, 3, 355-70.

Natile, G. (2013), 'Higher education institutions between a global and a local challenge', Portland Press, 153-166.

Noe, R. A. (1986), 'Trainees' attributes and attitudes: neglected influences on training effectiveness', Academy of Management Review, 11, 4, 736-49.

Noe, R. A., Tews, M. J. and McConnell-Dachner, A. (2010), 'Learner engagement: a new perspective for enhancing our understanding of learner motivation and workplace learning', Academy of Management Annals, 4, 279-315. 
Núñez-Cacho, P., Grande, F. A. and Lorenzo, D. (2015), 'The effects of coaching in employees and organizational performance: the Spanish case', Intangible Capital, 11, 2, 166-89.

Olavarrieta, S. and Friedmann, R. (1999), 'Market-oriented culture, knowledge-related resources, reputational assets and superior performance: a conceptual framework', Journal of Strategic Marketing, 7, 4, 215-28.

Paracha, O. S., Ismail, W. K. W. and Amin, S. M. (2014), 'The concept of HPWS-performance relationship: framework for education industry', Intangible Capital, 10, 3, 664-95.

Park, Y. and Choi, W. (2016), 'The effects of formal learning and informal learning on job performance: the mediating role of the value of learning at work', Asia Pacific Education Review, 17, 2, 279-87.

Pastor, J. M., Serrano, L., Pérez, F., Soler, A., Zaera, I. and Hernández, L. (2011). 'La formación continua: ornamento en la prosperidad y refugio en la adversidad', in A. Caparrós (ed.), Investigaciones de Economía de la Educación, Vol. 6 (Madrid: Asociación de Economía de la Educación), pp. 754-73.

Pérez, C. (2009). Técnicas Estadísticas Multivariantes con SPSS (Madrid: Ibergaceta publicaciones S.L).

Rial, A., Varela, J., Abalo, J. and Lévy-Mangin, J. P. (2006). 'El análisis factorial confirmatorio', in J. Lévy-Mangin and J. Varela (eds), Modelización con Estructuras de Covarianzas en Ciencias Sociales (Oleiros: Netbiblo), pp. 119-54.

Rigby, M. and Ponce Sanz, Y. (2016), 'International briefing 34: training and development in Spain', International Journal of Training and Development, 20, 4, 302-14.

Ruiz, C. (2001). La evaluación de programas de formación de formadores en el contexto de la formación en y para la empresa. PhD thesis. Universidad Autónoma de Barcelona. Departamento de Pedagogía aplicada. Available at: http://www.tdx.cat/handle/10803/5003

Sabrià, B., Llinas, X., Isus, S. and Yáñez, C. (2012). Per què es cursa formació contínua en les Institucions d'Educació Superior? Elaboració $i$ validació d'una escala que permeti esbrinar els factors determinants en la demanda de formació contínua en les Institucions d'Educació Superior (Barcelona: Congreso Internacional Docencia Universitaria e Innovación (CIDUI 2012)).

Sarfati, H. (2013), 'Reflexiones sobre el tratamiento de la crisis del empleo en Europa', Revista Internacional del Trabajo, 132, 1, 163-77.

Satorra, A. (1990), 'Robustness issues in structural equation modeling: a review of recent developments', Quality and Quantity, 24, 4, 367-86.

Satorra, A. (2002), 'Asymptotic robustness in multiple group linear-latent variable models', Econometric Theory, 18, 2, 297-312.

Satorra, A. and Bentler, P. M. (2010), 'Ensuring positiveness of the scaled difference chi-square test statistic', Psychometrika, 75, 2, 243-8.

Silvi, R., and Cuganesan, S. (2006), 'Investigating the management of knowledge for competitive advantage: a strategic cost management perspective', Journal of Intellectual Capital, 7, 3, 309-23.

Solé-Parellada, F., Eguiguren-Huerta, M., Llinàs-Audet, X. and Pons-Peregort, O. (2006), 'Los aspectos económico-organizativos de la formación: una aproximación al caso de Cataluña', Universia Business Review, 9, 28-41.

St Pierre, A. and Kustcher, N. (2001). Pedagogía e Internet (Mexico: Trillas).

Sterck, G. and Baert, H. (2003). 'The impact of participation of employees on individual and organisation-directed learning settings in labour organisations', in Wider Benefits of Learning: Understanding and Monitoring the Consequences of Adult Learning (Lisbon: European Society for Research on the Education of Adults (ESREA)), pp. 223-32.

$\mathrm{Su}, \mathrm{Y}$. (2011), "The constitution of agency in developing lifelong learning ability: the "being" mode', Higher Education, 62, 4, 399-412.

Sutherland, P. and Crowther, J. (2007). Lifelong Learning: Concepts and Contexts (New York: Routledge).

Švarc, J. and Dabić, M. (2017), 'Evolution of the knowledge economy: a historical perspective with an application to the case of Europe', Journal of the Knowledge Economy, 8, 1, 159-76.

Tabuenca, B., Ternier, S. and Specht, M. (2013), 'Patrones cotidianos en estudiantes de formación continua para la creación de ecologías de aprendizaje', Revista De Educación a Distancia, 37, $1-13$.

Tennant, C., Boonkrong, M. and Roberts, P. A. B. (2002), 'The design of a training programme measurement model', Journal of European Industrial Training, 26, 5, 230-40.

Ubeda, M. (2005), 'Training and business performance: the Spanish case', International Journal of Human Resource Management, 16, 9, 1691-710.

Vlachos, I. (2008), 'The effect of human resource practices on organizational performance: evidence from Greece', International Journal of Human Resource Management, 19, 1, 74-97. 